LINK Working Paper Series

WP 01-03

Relating Career Stage to Attitudes towards HR Practices and Commitment: Evidence of Interaction Effects?

Edel Conway

The Learning, Innovation and Knowledge Research Centre DCU Business School Dublin City University

Glasnevin

Dublin 9

Ireland

link.dcu.ie 
THE LEARNING, INNOVATION AND KNOWLEDGE (LINK) RESEARCH CENTRE WORKING PAPER SERIES http://www.link.dcu.ie/publications/workingpaperseries/

(c) 2003, Relating Career Stage to Attitudes Towards HR Practices and Commitment: Evidence of Interaction Effects?, Edel Conway

Authors are responsible for the accuracy of citations, quotations, diagrams, tables and maps.

The views expressed here do not necessarily reflect those of Learning, Innovation and Knowledge (LInK) Research Centre.

All or part of this work may be reproduced for the purposes of study, research, criticism or review provided that the author and the Learning, Innovation and Knowledge (LInK) Research Centre are fully acknowledged.

THE LEARNING, INNOVATION AND KNOWLEDGE (LINK) RESEARCH CENTRE WORKING PAPER SERIES WP 01-03

http://www.link.dcu.ie/publications/workingpaperseries/

(c) 2003, LInK, Edel Conway

Contact: edel.conway@dcu.ie 


\title{
Relating Career Stage to Attitudes towards HR Practices and Commitment: Evidence of Interaction Effects?
}

\author{
EDEL CONWAY
}

\begin{abstract}
A dominant theme within the HRM literature concerns the identification of 'best practices' that will enhance both organisational performance and employee commitment. Though research exploring the impact of these practices at the level of the individual is considerably limited, it is implied that they may be applied both across and within organisations, yielding favourable firm level outcomes and employee behaviours. There is growing support among researchers for a more complex understanding of commitment. Meyer and Allen (1997) suggest that commitment is best viewed as multi-dimensional, comprising affective, continuance and normative dimensions. Employees displaying each dimension of commitment will remain in an organisation because they feel that they want to, need to or ought to do so. Research suggests that certain organisational and individual variables are related to different forms of commitment. There is also evidence that both commitment and work attitudes differ over the stages of an employee's career. This presents the possibility that organisations seeking to promote commitment may need to tailor HR practices to suit employees' needs, thus challenging the best practice perspective at the employee level. This paper extends on the literature by examining whether career stage has a moderating influence on the HR-commitment relationship. The empirical research is based on an employee attitude survey within three financial service organisations in Ireland $(\mathrm{N}=288)$. Using moderated multiple regression, the findings highlight the extent to which interaction effects are evident regarding attitudes towards HR practices and continuance and normative commitment, though not affective commitment. The implications of these findings for the management of commitment are discussed.
\end{abstract}

Key Words: Organisational Performance; Employee Commitment

THE LEARNING, INNOVATION AND KNOWLEDGE (LINK) RESEARCH CENTRE WORKING PAPER SERIES WP 01-03

http://www.link.dcu.ie/publications/workingpaperseries/

(c) 2003, LInK, Edel Conway

Contact: edel.conway@dcu.ie 


\title{
THE NATURE OF EMPLOYEE COMMITMENT
}

Over the last three decades, organisational commitment has emerged as a key concept in the study of work attitudes and behaviour (Meyer and Allen, 1997). Yet, there exists a considerable degree of diversity and controversy within the literature regarding how the construct should be defined and subsequently measured. Most definitions concern an individual's identification with the goals and values of an organisation (e.g. Buchanan, 1974; Porter et al, 1974). However, some consider both identification and involvement as forming the basis of a moral attachment to the organisation (e.g. Hall and Schneider, 1972; Wiener, 1982). Others identify what can be broadly termed as cost-based commitment, where an individual assesses the perceived 'gains' associated with continued membership of an organisation, and the perceived 'costs' associated with leaving (e.g. Becker, 1960; Rusbult and Farrell, 1983). Due to the lack of consensus regarding how commitment should be defined, it has been suggested that researchers recognise the complexity of the construct and view commitment as multi-faceted (Benkhoff, 1997). Meyer and Allen (1991, p. 67) propose one such conceptualisation of commitment comprising three separable components, each of which reflect a unique underlying psychological state. They provide a description of each of these commitment forms as follows:

\begin{abstract}
Affective commitment refers to the employee's attachment to, identification with, and involvement in the organisation. Employees with a strong affective commitment continue employment with the organisation because they want to do so. Continuance commitment refers to an awareness of the costs associated with leaving the organisation. Employees whose primary link to the organisation is based on continuance commitment remain because they need to do so. Finally, normative commitment reflects a feeling of obligation to continue employment. Employees with a high level of normative commitment feel that they ought to remain with the organisation.
\end{abstract}

Meyer and Allen suggest that individuals may display each of these three forms of commitment to varying degrees. Thus, the widely held definitions which emphasise commitment to organisational goals are problematic because according to this definition, people can be committed to an organisation for reasons other than a commitment to its goals.

Due to its predominately firm level focus, research investigating 'high commitment' management has not adequately recognised the complexity of the commitment construct and has failed to measure it. The concept of commitment depicts an individual attitude and high levels of commitment can only be assumed to exist if the actual commitment levels among a workforce are assessed.

\section{High Commitment Management Research}

Research examining 'high commitment management' in HRM has its roots in both the configurational and the universal theoretical frameworks. The configurational approach adopts a 'systems' perspective and attempts to identify patterns or 'bundles' of HR practices, which when used in association with each other, or with a particular

THE LEARNING, INNOVATION AND KNOWLEDGE (LINK) RESEARCH CENTRE WORKING PAPER SERIES WP 01-03

http://www.link.dcu.ie/publications/workingpaperseries/

(C) 2003, LInK, Edel Conway

Contact: edel.conway@dcu.ie 
strategy, predict better performance (Delery and Doty, 1996; Huselid, 1995). This perspective posits that the combination of practices comprising the HR system is of greater value - both in terms of organisational performance and in fostering appropriate employee behaviours - than the adoption of particular practices in isolation. The universal or 'best practice' approach posits that certain HR practices lead to higher performance and therefore should be adopted by all organisations, irrespective of the basis upon which they seek to compete (Pfeffer, 1994; 1998). Delery and Doty (1996) suggest that HR practices that have been consistently related to firm performance - either theoretically or empirically - may be regarded as 'strategic' or generic 'best' HR practices.

Table 1 identifies those HR practices that have been commonly termed as 'high performance', 'high commitment' or 'best' HR practices within the literature. These practices can be broadly classified in terms of their impact on employees' skills and ability, motivation, and the way that work is structured (Huselid, 1995).

[Insert Table 1 about here]

A number of studies have reported associations between 'systems' of these practices and outcomes such as turnover, absenteeism, productivity levels and firm performance (e.g. Huselid, 1995; MacDuffie, 1995). A smaller number of studies have investigated the extent to which 'high commitment management' has been adopted within organisations (e.g. Arthur, 1994; Wood and DeMenezes, 1998; Roche, 1999), investigating similar practices as those associated with high performance, and in some cases reporting similar firm-level outcomes. As a result of this research, the literature now refers to the adoption of what are now termed 'high performance' and somewhat more loosely, 'high commitment' HR practices.

\section{Linking Commitment to Performance}

The simultaneous use of the terms 'high commitment' and 'high performance' in relation to these practices implies that the relationship between commitment and performance is well established. Yet, a number of research studies suggest that this relationship is weak (e.g. Mowday et al, 1982; Lee and Mowday, 1987; Shore and Martin, 1989). A small number of studies viewing commitment as a multidimensional construct have reported relationships between affective commitment and performance in particular (Angle and Lawson, 1994; Caruana et al, 1998; Hackett et al, 1994; Meyer et al, 1989; Suliman and Iles, 2000). For example, Meyer and his colleagues have found that affective commitment is associated with higher productivity (Meyer et al, 1989), more positive work attitudes (Allen and Meyer, 1996) and more organisational citizenship behaviours (Meyer and Allen, 1991). Research also suggests that affective commitment is associated with absenteeism (Hackett et al, 1994; Iverson and Buttigieg, 1999; Mathieu and Zajac, 1990; Meyer et al, 1993, Somers, 1995) and financial performance (DeCotiis and Summers, 1987).

THE LEARNING, INNOVATION AND KNOWLEDGE (LINK) RESEARCH CENTRE WORKING PAPER SERIES WP 01-03

http://www.link.dcu.ie/publications/workingpaperseries/

(C) 2003, LInK, Edel Conway

Contact: edel.conway@dcu.ie 
Fewer investigations have reported links between commitment and normative or continuance dimensions of commitment. However, some studies have reported either no relationship between continuance commitment and performance, or a negative one (e.g. Angle and Lawson, 1994; Caruana et al, 1998; Konovsky and Cropanzano, 1991; Meyer et al, 1989; Somers and Birnbaum, 1998). Other studies have reported no significant relationships between normative commitment and performance (e.g. Caruana et al, 1998; Hackett et al, 1994).

Regarding the establishment of linkages between HRM, commitment and performance, Edwards and Wright (2001, p. 570) suggest that it remains rare for studies to assess all the links in the chain, with the effects on employee commitment being a particularly rarely studied issue'. If high commitment is necessary for high performance, then commitment may represent the critical link missing from this research (Whitfield and Poole, 1997). Research to date would suggest that it is the HR practices that foster affective commitment that will have the performance-enhancing effect. This would suggest that organisations seeking to pursue high commitment strategies should focus on those practices that impact on the affective commitment of employees. However, an understanding of the relationships between attitudes towards HR practices and both normative and continuance commitment will also be useful in ensuring that HR practices do not promote undesirable behaviours.

\section{Managing Employee Commitment: A Universal Perspective?}

Walton (1985) suggests that commitment strategies can be applied universally across organisations; a view that is somewhat consistent with perspectives in the recent best practice literature. A key question, however, concerns whether commitment strategies can be applied universally for all employees within an organisation, and yield the same behavioural outcomes. Some commentators reject this notion. For example, Baron and Kreps (1999, p. 29) argue that:

no single approach to human resource management is universally applicable. Employees are people, and people are complex. They interact in complex ways with each other, with customers, with technology, and with strategy.

This implies that the universal application of high commitment practices may yield inconsistent employee outcomes because employees' experiences of these practices will vary. Lepak and Snell (1999) argue that it may be inappropriate and monolithic to suggest that there is a common bundle of practices for managing all of a firm's employees. They agree with that while a dominant HR strategy or 'architecture' may exist (Becker and Gerhart, 1996), at an operational level multiple bundles of practices may develop that are unique to particular employee sub-groups. They argue that just as there may be no universally best set of HR practices for every firm ... there may be no one best set of practices for every employee within a firm' $(1999, \mathrm{p} .45)$. Morris et al (1993) also question whether 'blanket' human resource policies can have the desired influence on commitment levels. They suggest:

THE LEARNING, INNOVATION AND KNOWLEDGE (LINK) RESEARCH CENTRE WORKING PAPER SERIES WP 01-03

http://www.link.dcu.ie/publications/workingpaperseries/

(c) 2003, LInK, Edel Conway

Contact: edel.conway@dcu.ie 
...what one employee regards as good career prospects may be regarded as mediocre by another and, while some employees may be committed to the organisation because of the job security it offers, others may be committed because of the nature of the work (pp. 37 - 38).

There are claims that a 'new generation' of employees seeks greater independence, autonomy, and flexibility because priorities are now shared between work, leisure and family life (Rothwell, 1995). Therefore organisations seeking to enhance the commitment of their workforce may need to consider changing attitudes and factors which affect them.

\section{HRM and Career Stage}

It has been suggested that as people progress through various stages of their careers, their work-related experiences vary considerably (Levinson, 1978; Super, 1957; VanMaanen and Schein, 1979). Schalk and Freese (1997, p. 120) suggest:

Often different perspectives are found in the workforce. For example, young people with little job experience might like to be offered extensive training, so they are able to find another job more easily. Older people might prefer more flexible and higher pension benefits, so they won't have to worry so much about their income after they retire ... Organisations could take this into account, for example, by offering choices from a certain variety of provisions, reflecting an intersection across the different employee perspectives.

A number of studies have shown that employee work attitudes differ across career stages (e.g. Allen and Meyer, 1993; Cron and Slocum, 1986; Guthrie and Schwoerer, 1996; Lynn et al, 1996; Mehta et al, 2000; Sturges et al, 2000). Some of these studies focus on the value or importance of particular HR practices to employees, while others examine satisfaction with these practices. For example, research among a graduate sample in the UK supports the view that career management is important during early career stages (Sturges et al, 2000). In contrast, however, Mehta et al (2000) found evidence to suggest that sales managers in later career stages place greater importance on opportunities for promotion.

It has also been postulated in the literature that older employees have, or at least perceive they have, more positive work experiences than do younger employees (Allen and Meyer, 1993; Cherrington et al, 1979). However, there is also evidence that aspiration for, and satisfaction with, certain organisational rewards (e.g. promotion or pay) decrease with age (Meyer, 2001. Allen and Meyer (1993) found that employees were more affectively responsive to particular experiences during their early careers, such as well-defined and challenging jobs. Other research has found that during early career stages, employees perceive that they lack job involvement, challenge, promotion opportunities and discretion in decision making (Cron and Slocum, 1986). Lincoln and Kalleberg (1990) found evidence to suggest that older employees experience greater autonomy and intrinsic rewards, often as a result of promotion.

THE LEARNING, INNOVATION AND KNOWLEDGE (LINK) RESEARCH CENTRE WORKING PAPER SERIES WP 01-03

http://www.link.dcu.ie/publications/workingpaperseries/

(c) 2003, LInK, Edel Conway

Contact: edel.conway@dcu.ie 


\section{Career Stage and Commitment}

A number of research studies also suggest that commitment will vary over the course of people's careers (Allen and Meyer, 1993; Cohen, 1991; Mathieu and Zajac, 1990; Suliman and Iles, 2000). Research indicates that age is positively related to organisational commitment (e.g. Mathieu and Zajac, 1990; Meyer and Smith, 2000), even when controlling for both positional and organisational tenure (e.g. Allen and Meyer, 1993). This would suggest that employee age represents the real career stage effect on affective commitment and that older employees are more affectively committed than younger employees, perhaps due to more positive work experiences (Allen and Meyer, 1993). However, further meta-analytic studies suggest that there is a positive relationship between attitudinal or affective commitment and organisational tenure (Cohen, 1993; Mathieu and Zajac, 1990; Meyer and Smith, 2000). O'Reilly and Chatman (1986) suggest that this is because employees with longer tenure will identify more with the goals of the organisation and will be more willing to exert extra effort in achieving these goals. It has also been suggested that commitment may develop simply as a result of the longevity of the employment relationship (Gaertner and Nollen, 1989; Ogilvie, 1986).

There is evidence to suggest that age and tenure are antecedents to the development of calculative (e.g. Alutto et al, 1973; Buchanan, 1974; Farrell and Rusbult, 1981; Ferris and Aranya, 1983) and continuance commitment (e.g. Allen and Meyer, 1993; Hackett et al, 1994; Meyer and Smith, 2000; Reilly and Orsak, 1991; Somers, 1993). This suggests that perceptions of the investments accumulated within an organisation (and therefore costs associated with leaving) will increase with employee age and tenure.

Studies by Allen and Meyer (1993) and Taormina (1999) have found that age is a significant predictor of normative commitment. Hackett et al (1994) reported that organisational tenure was positively associated with normative commitment among their sample of nurses. They suggest that 'research concerning the possible differential antecedents of [affective, continuance and normative commitment] should continue' (Hackett et al, 1994, p.21).

\section{HIGH COMMITMENT MANAGEMENT: AN INDIVIDUAL PERSPECTIVE}

The research findings explored here suggest that it is possible that heterogeneity among employees will result in different attitudes towards HR practices, even if these practices are applied consistently. Furthermore, they suggest that attitudes towards certain HR practices will be more important at particular stages of a career than others, which may in turn lead to varying levels of commitment. Career stage, therefore, challenges the universal applicability of HR practices to all employees within an organisation. This suggests that it is possible that no one set of practices can be universally applied across all employees, but that perhaps a series of individualised

THE LEARNING, INNOVATION AND KNOWLEDGE (LINK) RESEARCH CENTRE WORKING PAPER SERIES WP 01-03

http://www.link.dcu.ie/publications/workingpaperseries/

(C) 2003, LInK, Edel Conway

Contact: edel.conway@dcu.ie 
contracts for employees is required (Herriot and Pemberton, 1997). To test this possibility it is hypothesised that:

Hypothesis 1: Organisational commitment will vary according to career stage, as measured by employee age and organisational tenure.

Hypothesis 2: Attitudes towards HR practices will vary according to career stage, as measured by age and organisational tenure.

Hypothesis 3: Attitudes towards HR practices will interact with career stage to predict affective, continuance and normative commitment.

It has been suggested that more research is needed to identify conditions that might moderate the relationships between antecedent variables and commitment (Meyer, 2001; Meyer and Allen, 1997). By investigating such relationships, an otherwise unnoticed connection between two variables may be found. Katz (1978), for example, found evidence for interaction effects regarding job satisfaction and organisational tenure. He found that new employees responded more positively to feedback from the job and to task significance, but responded negatively to job autonomy.

\section{METHOD}

The study was conducted within three financial services organisations in Ireland. Two of these organisations are multi-nationals, which are both non-unionised and one is an Irish organisation with a trade union presence. The senior Human Resource representatives within each of the three organisations distributed questionnaires to employees. Participation in the study was entirely voluntary and respondents remained anonymous.

A total of 435 questionnaires were distributed within the three organisations; 288 of which were completed and returned, yielding an overall response rate of 68 per cent. The sample comprises representatives from a variety of positions including managerial/ supervisory, clerical and administrative staff. A high proportion of the sample is aged 30 years or younger (58 per cent). Over one third (36 per cent) of respondents have been employed by their organisation for two years or less, while the highest proportion (39 per cent) have been employed for between 2 and 10 years. One quarter of the sample has been employed for 10 or more years.

\section{Measures}

Organisational commitment. Allen and Meyer's (1990) measure of commitment was employed. This measure consists of three sub-scales measuring affective, continuance and normative commitment. Using a 5-point Likert-type format, responses ranged from strongly disagree (-2) to strongly agree $(+2)$, with higher scores indicating

THE LEARNING, INNOVATION AND KNOWLEDGE (LINK) RESEARCH CENTRE WORKING PAPER SERIES WP 01-03 
higher levels of each form of commitment. Reliabilities for the affective, continuance and normative sub-scales were $0.81,0.76,0.71$ respectively.

Human Resource Management Practices. A thorough review of the literature was carried out to identify HR practices that have been associated with high commitment management. A 52-item instrument was developed to elicit employee attitudes towards a variety of HR practices, based on those practices identified within previous studies. Responses were based on a 5-point Likert-type scale, with scores ranging from 'strongly disagree' (-2) to 'strongly agree' $(+2)$. To evaluate the overall validity of this measure all items were entered in a factor analysis, which led to the development of the following scales: involvement $(\alpha=.84)$, reward $(\alpha=.82)$, performance management $(\alpha=.80)$, resourcing and integration $(\alpha=.82)$, job design ( $\alpha=.76$ ), career development ( $\alpha=.72$ ), training ( $\alpha=.77$ ), employability ( $\alpha=.72$ ) and teamwork $(\alpha=.59)$. A single item measure of job security was also included. In view of the relatively poor reliability of the teamwork measure, it was decided to exclude this variable from the predictor models of the research. A summary of sample items included in the questionnaire is provided in Table 2.

[Insert Table 2 about here]

Career Stage. Career stage was defined by two variables: age and organisational tenure. Employee age was categorised in three groupings: 30 years or under, 31 to 40 years, 41 years or more. Employees were asked to state the length of time (years and months) in their current employment, so organisational tenure was coded as a continuous variable. Consistent with other similar research on employee commitment (Morrow \& McElroy, 1987; Allen \& Meyer, 1993), this variable was subsequently defined by three categories: less than 2 years, between 2 and 10 years, and more than 10 years.

Other Demographic Variables. These variables included job status, education and position occupied within the organisation (all coded 1 to 5), where higher scores indicate higher job status, education and position occupied. A variable relating to gender was also included $(1=$ male and $2=$ female $)$.

\section{RESULTS}

The correlations presented in Table 3 show the magnitude of the relationships between the main variables of interest to the study.

[Insert Table 3 about here]

Regarding hypothesis 1, there is a weak but positive and significant relationship between employee age and affective commitment, suggesting that levels of affective

THE LEARNING, INNOVATION AND KNOWLEDGE (LINK) RESEARCH CENTRE WORKING PAPER SERIES WP $01-03$

http://www.link.dcu.ie/publications/workingpaperseries/

(c) 2003, LInK, Edel Conway

Contact: edel.conway@dcu.ie 
commitment are higher among older respondents. There is a stronger and significant relationship between organisational tenure and affective commitment, which shows that affective commitment also increases as tenure increases. Regarding continuance commitment, the relationship with employee age is not significant, but there is a positive relationship with organisational tenure $(r=0.29)$, suggesting that continuance commitment increases as tenure increases. No significant relationships are apparent between either career stage variable and normative commitment.

With respect to hypothesis 2 , these correlations also show that older and longer serving respondents view job design and rewards more positively, and involvement and resourcing less positively, than younger or shorter serving respondents. However, attitudes towards job security and teamwork are less positive among older respondents.

While these correlations provide some degree of support for hypotheses 1 and 2, it is important to recognise that a high correlation exists between employee age and organisational tenure $(r=0.62)$. In order to isolate the relative influence of each career stage indicator on these variables, partial correlations were carried out. These correlations between career stage and commitment variables are presented in Table 4.

[Insert Table 4 around here]

This analysis shows that the relationship between employee age and affective commitment is no longer apparent when controlling for organisational tenure. However, the relationship between organisational tenure and affective commitment remains significant, albeit weaker, when controlling for employee age. In addition, the relationship between organisational tenure and continuance commitment remains significant. This suggests that organisational tenure might represent the 'real' career stage influence on both affective and continuance commitment.

The partial correlations between both career stage variables and attitudes towards HR practices are presented in Table 5.

[Insert Table 5 around here]

The relationships between age, involvement, teamwork $(\mathrm{p}<0.05)$ and job security $(\mathrm{p}$ $<0.01)$ are still significant when controlling for organisational tenure. When partialling out employee age, the analysis indicates that the relationships between tenure, reward and resourcing and integration also remain significant $(\mathrm{p}<0.01)$. These findings therefore suggest that the 'real' career stage influence on employee involvement, job security and teamwork is employee age, but that the 'real' career stage effects on resourcing and integration and employee reward is organisational tenure. Partial correlations between career stage and affective commitment show that the relationship between employee age and affective commitment is no longer apparent when controlling for organisational tenure $(r=-.03)$. However, the relationship between tenure and affective commitment remains significant, albeit

THE LEARNING, INNOVATION AND KNOWLEDGE (LINK) RESEARCH CENTRE WORKING PAPER SERIES WP 01-03

http://www.link.dcu.ie/publications/workingpaperseries/

(c) 2003, LInK, Edel Conway

Contact: edel.conway@dcu.ie 
weaker, when controlling for employee age $(\mathrm{r}=.21, \mathrm{p}<.001)$. This suggests that organisational tenure might represent the 'real' career stage influence on affective commitment.

Hypothesis 3 posits that the relationship between attitudes towards HR practices and affective, continuance and normative commitment will be moderated by career stage. The approach used to conduct this analysis was similar to that used to investigate moderated relationships in other research (Allen and Meyer, 1993; Katz, 1978; Kemp and Cook, 1983). In the first instance, subgroup correlations were examined by splitting the data file according to age and tenure categories respectively. These correlations with respect to affective commitment are presented in Table 6.

[Insert Table 6 around here]

As this table shows, attitudes towards all HR practices were significantly related to affective commitment among respondents aged 30 years or younger. Significant relationships were found between career development, job design, involvement, job security, performance management, teamwork and affective commitment with respect to respondents' aged between 31 and 40 years. Significant relationships were also found between performance management, employability, involvement, resourcing and integration, reward and affective commitment for respondents aged 41 years or older.

With the exception of job security, employability and reward, attitudes towards all HR practices were significantly related to affective commitment for respondents with less than two years' service. With the exception of teamwork, attitudes towards all HR practices were significantly related to affective commitment for respondents with between two and ten years' service. The relationships between attitudes towards each of the HR practices and affective commitment were significant for respondents with 10 years or more service.

To test for moderated relationships, each dimension of commitment was regressed on the independent variables and the cross-product or interaction of these variables. In order to minimise multi-collinearity, scores for all independent variables were centered at the mean as recommended by Aiken and West (1991). Predictors of commitment were entered as follows: the career stage variables entered as a block; the particular HR practice variable; the interaction between the HR practice variable and employee age; and finally the interaction between the HR practice variable and organisational tenure. As each variable was added, the predictive power of the equation was assessed by examining the incremental change in the $\mathrm{F}$ value. Table 7 shows the multiple correlations for affective commitment regressed on career stage, the HR practice areas and their interactions.

[Insert Table 7 around here]

This analysis shows that both career stage and, more notably, attitudes towards HR practices represent significant predictors of affective commitment. It is also indicated,

THE LEARNING, INNOVATION AND KNOWLEDGE (LINK) RESEARCH CENTRE WORKING PAPER SERIES WP $01-03$

http://www.link.dcu.ie/publications/workingpaperseries/

(c) 2003, LInK, Edel Conway

Contact: edel.conway@dcu.ie 
however, that attitudes towards HR practices do not interact significantly with either age or tenure in predicting affective commitment. Therefore, no support for Hypothesis 3 with respect to affective commitment has been found.

Table 8 reports partial correlations between each career stage variable and continuance commitment.

[Insert Table 8 around here]

This table shows that with respect to respondents aged 30 years or less, performance management, job security, reward and teamwork were significantly and positively related to continuance commitment. Regarding respondents aged between 31 and 40 years, there was a significant and negative relationship found between job security and continuance commitment. There was also a positive relationship found between employee reward and continuance commitment regarding respondents aged 41 years or more.

Regarding organisational tenure, no significant relationships were found between attitudes towards HR practices and continuance for those employed two years or less. For those with between two and ten years' service, there was a significant and positive relationship found between job security and continuance commitment. Finally, there was a significant and positive relationship between employee reward and continuance commitment regarding those employed 10 years or more.

Table 9 reports multiple correlations for both career stage variables and HR practice areas in the prediction of continuance commitment.

[Insert Table 9 around here]

This analysis shows evidence for a moderating influence between employee age and attitudes towards performance management in the prediction of continuance commitment. Further examination of the partial correlations presented in Table 8 indicates that attitudes towards performance management are more positively related to a 'need' to stay within the organisation among respondents aged 30 years or less. On the basis of this finding, Hypothesis 3 is partially supported. However, there was no evidence to suggest that organisational tenure moderated the relationship between attitudes towards HR practices and the development of continuance commitment.

Partial correlations with respect to normative commitment are presented in Table 10.

[Insert Table 10 around here]

For respondents aged 30 years or younger, significant relationships were found between career development, job design, resourcing and integration, reward, involvement and normative commitment. Employability was negatively related to the development of normative commitment among respondents' aged between 31 and 40

THE LEARNING, INNOVATION AND KNOWLEDGE (LINK) RESEARCH CENTRE WORKING PAPER SERIES WP $01-03$

http://www.link.dcu.ie/publications/workingpaperseries/

(c) 2003, LInK, Edel Conway

Contact: edel.conway@dcu.ie 
years. No significant relationships were found between attitudes towards HR practices and normative commitment for respondents aged 41 years or older.

Regarding organisational tenure and normative commitment, significant relationships are evident regarding job design, career development, employee involvement and performance management for respondents with service of two years or less. In addition, significant relationships were found between resourcing and integration, employee reward, job security and normative commitment for respondents with tenure between two and ten years. No significant relationships were found regarding normative commitment with respect to those employed for 10 years or more.

Table 11 shows multiple correlations for each of the key variables in the study and normative commitment.

\section{[Insert Table 11 around here]}

Consistent with the previous analyses, the table shows that career stage is not a significant predictor of normative commitment. Those significant HR predictors are career development, employee resourcing and integration, job design, performance management and employee involvement. A significant moderated relationship with respect to employee age was also found regarding career development, job design and employability. Examination of the partial correlations in Table 10 shows that there is a significant and positive relationship between these practices and normative commitment for respondents aged 30 years or less. This would suggest that when these practices are viewed positively, employees within this age category are more likely to develop normative commitment. Further significant moderated relationships were evident with respect to organisational tenure and attitudes towards career development and employee involvement $(\mathrm{p}<0.05)$. Returning to Table 10, the analysis suggests that positive attitudes towards these practices among those with less than two years' service are associated with high levels of normative commitment.

\section{DISCUSSION}

The 'best practice' perspective posits that within a variety of organisational settings, certain HR practices can be adopted which will yield favourable performance outcomes. This research has unpacked and then repacked the relationships between career stage, attitudes towards HR practices and commitment in order to examine whether this perspective can be promulgated at the employee level. These findings, though preliminary, provide support for this perspective.

The research demonstrates that attitudes towards HR practices and commitment are differentially related to career stage, thus supporting hypotheses 1 and 2 . For example, it was found that respondents with longer service viewed reward practices more positively and resourcing and integration practices more negatively, when compared to those with shorter service. It was also found that older respondents held

THE LEARNING, INNOVATION AND KNOWLEDGE (LINK) RESEARCH CENTRE WORKING PAPER SERIES WP 01-03

http://www.link.dcu.ie/publications/workingpaperseries/

(c) 2003, LInK, Edel Conway

Contact: edel.conway@dcu.ie 
more negative attitudes towards opportunities for involvement and employment security when compared to those in the younger age categories. In addition, respondents with longer tenure i.e. more than ten years, were more inclined to display high levels of affective commitment and continuance commitment than were those with shorter tenure. It is conceivable that employees with longer tenure occupy more desirable positions, receive higher levels of extrinsic rewards and have developed closer relationships with work colleagues than those with shorter tenure (Mottaz, 1988; Meyer and Allen, 1997). For this reason, their perceptions of 'sunk costs' or investments in the organisation may be higher. It is also likely that respondents displaying high levels of continuance commitment perceive that their lengthy experience with their present employer makes them less employable elsewhere. The findings suggest that career stage has relatively little influence in the development of normative commitment. Though relatively few studies have investigated the influence of demographic variables on normative commitment, this finding has been supported elsewhere (Hackett et al, 1994). These findings initially suggest that in seeking to foster high commitment, the management of employee experiences across career stages might be usefully considered by organisations. They also seem to highlight some difficulty in promoting a best practice perspective at the individual level. The findings relating to hypothesis 3 , however, can shed further light on this issue.

It was posited that career stage would moderate the relationships between attitudes towards HR practices and commitment (Hypothesis 3). This would imply that HR practices might need to be configured according to career stage, thus leading to a rejection of the best practice perspective at the employee level. While the hypotheses concerning career stage, attitudes towards HR practices and commitment were supported to varying degrees, an important finding in the present study was that attitudes towards HR practices did not interact with career stage to predict affective commitment. This finding implies that organisations seeking to enhance affective commitment will benefit little from configuring HR practices to 'fit' with employees' career stages. Therefore, consistent with a best practice perspective, this finding implies that organisations can adopt these practices across all categories of employees ${ }^{1}$. The failure to find significant interaction effects regarding affective commitment is important from a practitioner perspective, since HR practices can be refined or re-defined while career stage can not.

The finding that organisational tenure, and not age, is a significant predictor of commitment is also important for organisations wanting to retain skilled and experienced staff. Though highly correlated with tenure, employee age does not necessarily signal the presence of valued skills and experience to the same extent that length of experience within an organisation does. This finding implies that the development of affective commitment represents an evolutionary process and that attention to the factors that influence affective commitment during the earlier stages of an individual's career is important.

${ }^{1}$ This argument applies to affective commitment and career stage only, as it is possible that interaction effects exist across other individual variables not examined in the study.

THE LEARNING, INNOVATION AND KNOWLEDGE (LINK) RESEARCH CENTRE WORKING PAPER SERIES WP 01-03

http://www.link.dcu.ie/publications/workingpaperseries/

(c) 2003, LInK, Edel Conway

Contact: edel.conway@dcu.ie 
The sub-group correlations performed across career stage categories do provide some general indications of ways in which affective commitment can be optimised in organisations. In particular, they suggest that early work experiences are important determinants of organisational commitment. This is important since the findings indicate that both younger and shorter tenured employees are less likely to be affectively committed to their organisation. The practices that were consistently associated with higher levels of affective commitment during early career stages (both age and tenure) were job design, employee involvement and career development. This suggests that organisations concerned with improving levels of affective commitment must emphasise these practices during early career stages.

The analysis found that, in most cases, attitudes towards individual HR practices did not interact with career stage to influence continuance commitment. Interaction effects were, however, evident with respect to employee age, attitudes towards performance management. This suggests that positive attitudes towards performance management among younger employees are likely to influence levels of continuance commitment. This is perhaps due to the expectation that increased rewards, perceived as added investments, might result from the performance management process.

A number of moderated relationships emerged regarding career stage and attitudes towards HR practices in the prediction of normative commitment. The analysis found that both employee age and organisational tenure interacted with career development in the prediction of normative commitment. The relationship between career development and normative commitment was strongest among those employees aged 30 years or younger, and those employed by the organisation for two years or less. It has been suggested that normative commitment can be influenced by investments that seem difficult for employees to replicate (Meyer and Allen, 1997). It therefore seems that employees, who perceive that they are fortunate to enjoy promotion opportunities at an early age, or during the early stages in their tenure, are more likely to experience feelings of obligation or indebtedness.

The analysis found further evidence for interaction effects between tenure and attitudes towards employee involvement in the prediction of normative commitment. This finding implies that those with less than two years of service who view employee involvement practices positively, are more likely to display high levels of normative commitment. Since employee involvement initiatives demonstrate a concern for employee interests, this is likely to result in reciprocal feelings of concern and obligation on the part of employees.

Further moderated relationships were evident regarding employee age and attitudes towards both job design and employability in the prediction of normative commitment. This suggests that more positive attitudes towards job design among those aged 30 years or younger are associated with higher levels of normative commitment. This finding implies that organisational efforts to improve the design of jobs by optimising the use of skills and abilities, providing interesting work and by

THE LEARNING, INNOVATION AND KNOWLEDGE (LINK) RESEARCH CENTRE WORKING PAPER SERIES WP 01-03

http://www.link.dcu.ie/publications/workingpaperseries/

(c) 2003, LInK, Edel Conway

Contact: edel.conway@dcu.ie 
promoting a high degree of autonomy, are associated with feelings of obligation to remain among younger employees.

It was also found that positive perceptions of employability were significantly related to lower levels of normative commitment among employees aged between 31 and 40 years. This suggests that for this age category, perceptions of one's employability outside the organisation are not associated with feelings of obligation to remain. This finding is interesting because the relationship between employability for this age category was negatively associated with continuance commitment (i.e. needing to remain), but was not related to affective commitment.

In most cases, the significant interactions were apparent regarding younger or shorter tenured employees, who were also those less likely to display high affective commitment. This implies that emphasising certain practices during early career stages may impact on levels of continuance or normative commitment. By doing so, the overall performance and wellbeing of employees during early career stages may not be optimal, unless those practices associated with affective commitment are also emphasised.

The lack of focus on employee experiences of HR practices has represented a notable weakness in the literature because it conflicts with much of the rhetoric and underlying theory in HRM. The focus of this research on individual differences that might impact on how employees view HR practices, and how they subsequently view their attachment to the organisation, has provided a better understanding of the complex HR commitment relationship. Overall, the research has implications for the management of employee experiences of HRM, commitment and, indirectly at least, for the management of performance within organisations.

\section{REFERENCES}

Aiken, Leona S. and West, Stephen G. 1991. Multiple Regression: Testing and Interpreting Interactions. Newbury Park, CA: Sage.

Allen, Natalie J. and Meyer, John P. 1990. 'The measurement and antecedents of affective, continuance and normative commitment to the organisation', Journal of Occupational Psychology, Vol. 63, No. 1, pp. 1-18.

Allen, Natalie J. and Meyer, John P. 1993. 'Organizational commitment: evidence of career stage effects?', Journal of Business Research, Vol. 26, No. 1, pp. 49-61.

Allen, Natalie J. and Meyer, John P. 1996. 'Affective, continuance and normative commitment to the organisation: an examination of construct validity', Journal of Vocational Behavior, Vol. 49, pp. 252-276.

Angle, Harold L. and Lawson, Marian B. 1994. 'Organizational commitment and employees' performance ratings: both type of commitment and type of performance count', Psychological Reports, Vol. 75, No. 3, pp. 1539-1551.

THE LEARNING, INNOVATION AND KNOWLEDGE (LINK) RESEARCH CENTRE WORKING PAPER SERIES WP 01-03

http://www.link.dcu.ie/publications/workingpaperseries/

(c) 2003, LInK, Edel Conway

Contact: edel.conway@dcu.ie 
Arthur, Jeffrey B. 1994. 'Effects of human resource systems on manufacturing performance and turnover', Academy of Management Journal, Vol. 37, No. 3, pp. 670-687.

Baron, James and Kreps, David 1999. 'Consistent human resource management practices', California Management Review, Vol. 41, No. 3, pp. 30-53.

Becker, Howard S. 1960. 'Notes on concept of commitment', American Journal of Sociology, Vol. 66, pp. 32-40.

Becker, Brian E. and Gerhart, Barry 1996. 'The impact of human resource management on organisational performance: progress and prospects', Academy of Management Journal, Vol. 39, No. 4, pp. 770-801.

Benkhoff, Birgit 1997. 'Disentangling organisational commitment: the dangers of the OCQ for research and policy', Personnel Review, Vol. 26, No.1/2, pp. 114-131.

Buchanan, Bruce. 1974. 'Building organizational commitment: the socialization of managers in work organizations', Administrative Science Quarterly, Vol. 19, pp. 533-546.

Caruana, Albert, Ewing, Mike and Ramaseshan, Ram 1998. 'Organisational commitment and performance', Proceedings of the Seventh Annual World Business Congress, pp. 27-33.

Cherrington, David J., Condie, Spencer J. and England, Lynn J. 1979. 'Age and work values’, Academy of Management Journal, Vol. 22, No.3, pp. 617-623.

Cohen, Aaron 1993. 'Organizational commitment and turnover: a meta-analysis', Academy of Management Journal, Vol. 36, No. 5, pp. 1140-1159.

Cron, William L. and Slocum, John W. 1986. 'The influence of career stages on salespeople's job attitudes, work perceptions, and performance', Journal of Marketing Research, Vol. 23, No.2, pp. 119-129.

DeCotiis, Thomas A. and Summers, Timothy P. 1987. 'A path analysis of the antecedents and consequences of organizational commitment', Human Relations, Vol. 40, No. 7, pp. 445-470.

Delery, John and Doty, Harold 1996. 'Modes of theorising in strategic human resource management: tests of universalistic, contingency and configurational performance predictions', Academy of Management Journal, Vol. 39, No. 4, pp. 802-835.

Edwards, Paul and Wright, Martyn 2001. 'High-involvement work systems and performance outcomes: the strength of variable, contingent and context-bound relationships, International Journal of Human Resource Management, Vol. 12, No. 4, pp. 568-585.

Gaertner, Karen N. and Nollen, Stanley D. 1989. 'Career experiences, perceptions of employment practices and psychological commitment to the organisation', Human Relations, Vol. 42, No. 11, pp. 975-991.

THE LEARNING, INNOVATION AND KNOWLEDGE (LINK) RESEARCH CENTRE WORKING PAPER SERIES WP 01-03

http://www.link.dcu.ie/publications/workingpaperseries/

(c) 2003, LInK, Edel Conway

Contact: edel.conway@dcu.ie 
Guest, David E. 1999. 'Human resource management - the workers' verdict', Human Resource Management Journal, Vol. 9, No.3, pp. 5-25.

Guthrie, James P. and Schwoerer, Catherine E. 1996. 'Older dogs and new tricks: career stage and self-assessed need for training', Public Personnel Management, Vol. 25, No. 1, pp. 59-72.

Hackett, Rick, Bycio, Peter and Hausdorf, Peter 1994. 'Further assessments of Meyer and Allen's (1991) three-component model of organizational commitment', Journal of Applied Psychology, Vol. 79, No. 1, pp. 15-23.

Hall, Douglas T. and Schneider, Benjamin 1972. 'Correlates of organizational identification as a function of career pattern and organizational type', Administrative Science Quarterly, Vol. 17, No.3, pp. 340-350.

Herriot, Peter and Pemberton, Carole 1997. 'Facilitating new deals', Human Resource Management Journal, Vol. 7, No. 1, pp. 45-56.

Huselid, Mark A. 1995. 'The impact of human resource management practices on turnover, productivity and corporate financial performance', Academy of Management Journal, Vol. 38, No. 3, pp. 635-672.

Iverson, Roderick D. and Buttigieg, Donna M. 1999. 'Affective, normative and continuance commitment: can the 'right' kind of commitment be managed?', Journal of Management Studies, Vol. 36, No. 3, pp. 307-333.

Konovsky, Mary A. and Cropanzano, Russell 1991. 'Perceived fairness of employee drug testing as a predictor of employee attitudes and job performance', Journal of Applied Psychology, Vol. 76, No. 5, pp. 698-707.

Lawler III, Edward.E., Mohram, S.A. and Ledford, G.E. Jr. 1998. Strategies for High Performance Organisations. San Francisco: Jossey-Bass.

Lee, Thomas W. and Mowday, Richard T. 1987. 'Voluntarily leaving an organisation: an empirical investigation of Steer's and Mowday's model of turnover', Academy of Management Journal, Vol. 30, No. 4, pp. 721-743.

Legge, Karen 1998. 'The morality of HRM', in Mabey, Christopher, Skinner, Denise and Clark, Timothy (Eds.) Experiencing Human Resource Management. London: Sage. pp. 14-30.

Lepak, David P. and Snell, Scott A. 1999. 'The human resource architecture: toward a theory of human capital allocation and development', Academy of Management Review, Vol. 24, No. 1, pp. 31-48.

Levinson, Daniel J. 1978. The Seasons of a Mans Life. New York: Knopf.

Lincoln, James R. and Kalleberg, Arne L. 1990. Culture, Control and Commitment: A Study of Work Organization and Work Attitudes in the United States and Japan. Cambridge: Cambridge University Press.

THE LEARNING, INNOVATION AND KNOWLEDGE (LINK) RESEARCH CENTRE WORKING PAPER SERIES WP 01-03

http://www.link.dcu.ie/publications/workingpaperseries/

(C) 2003, LInK, Edel Conway

Contact: edel.conway@dcu.ie 
Lynn, Susan A., Cao, Le Thi and Horn, Betty C. 1996. 'The influence of career stage on the work attitudes of male and female accounting professionals', Journal of Organizational Behavior, Vol. 17, No. 2, pp. 135-149.

MacDuffie, John Paul 1995. 'Human resource bundles and manufacturing performance: flexible production systems in the world auto industry', Industrial Relations and Labor Review, Vol. 48, No. 2, pp.197-221.

Mathieu, John E. and Zajac, D.M. 1990. 'A review and meta-analysis of the antecedents, correlates and consequences of organisational commitment', Psychological Bulletin, Vol. 108, No. 2, pp. 171-194.

Mehta, Rajiv, Anderson, Rolph E. and Dubinsky, Alan J. 2000. 'The perceived importance of sales managers' rewards: a career stage perspective', Journal of Business and Industrial Marketing, Vol. 15, No. 7, pp. 507-524.

Meyer, John P., Paunonen, Sampo V., Gellatly, Ian R., Goffin, Richard D. and Jackson, Douglas N. 1989. 'Organisational commitment and job performance: it's the nature of the commitment that counts', Journal of Applied Psychology, Vol. 74, No.1, pp. 152-156.

Meyer, John P. and Allen, Natalie J. 1991. 'A three-component conceptualisation of organisational commitment: Some methodological considerations', Human Resource Management Review, Vol. 1, No.1, pp. 61-89.

Meyer, John P., Allen, Natalie J. and Smith, Catherine A. 1993. 'Commitment to organizations: extension and test of three-component conceptualization', Journal of Applied Psychology, Vol. 78, No.4, pp. 538-551.

Meyer, John P. and Allen, Natalie J. 1997. Commitment in the Workplace: Theory, Research and Application. Thousand Oaks, CA: Sage.

Meyer, John P., Irving, Gregory P. and Allen, Natalie, J. 1998. 'Examination of the combined effects of work values and early work experiences on organizational commitment', Journal of Organizational Behavior, Vol. 19, No. 1, pp. 29-52.

Meyer, John P. and Smith, Catherine A. 2000. 'HRM practices and organizational commitment: test of a mediation model', Canadian Journal of Administrative Sciences, Vol. 12, No. 4, pp. 319-331.

Meyer, John 2001. 'Organisational commitment', in Cooper, Cary and Robertson, Ivan (Eds.) Personnel Psychology and Human Resource Management: A Reader for Students and Practitioners. Chichester: Wiley, pp. 289-342.

Monks, Kathy and McMackin, John, 2001. 'Designing and aligning an HR system', Human Resource Management Journal, Vol. 11, No. 2, pp57-62.

Morris, Tim, Lydka, Helen and Fenton-O'Creevey, Mark 1993. 'Can commitment be managed? A longitudinal analysis of employee commitment and human resource policies', Human Resource Management Journal, Vol. 3, No. 3, pp. 21-42.

THE LEARNING, INNOVATION AND KNOWLEDGE (LINK) RESEARCH CENTRE WORKING PAPER SERIES WP 01-03

http://www.link.dcu.ie/publications/workingpaperseries/

(c) 2003, LInK, Edel Conway

Contact: edel.conway@dcu.ie 
Morrow, Paula C. and McElroy, James C. 1987. 'Work commitment and job satisfaction over three career stages', Journal of Vocational Behaviour, Vol. 30, pp. 330-346.

Mowday, Richard T., Porter, Lyman W., and Steers, Richard 1982. Employee Organisational linkages: The Psychology of Commitment, Absenteeism, and Turnover. New York: Academic Press.

Ogilvie, John R. 1986. 'The role of human resource management practices in predicting organizational commitment', Group and Organizational Studies, Vol. 11, pp. 335359.

O'Reilly, Charles A. and Chatman, Jennifer A. 1986. 'Organizational commitment psychological attachment: the effects of compliance, identification and internalization on prosocial behavior', Journal of Applied Psychology, Vol. 71, pp. 492-499.

Osterman, Paul 1987. 'Choice of employment systems in internal labor markets', Industrial Relations, Vol. 26, No. 1, pp. 46-67.

Patterson, Malcolm G., West, Michael, Lawthom, Rebecca and Nickell, Stephen 1997. Impact of People Management Practices on Business Performance. London: Institute of Personnel and Development.

Pfeffer, Jeffrey 1994. Competitive Advantage Through People: Unleashing the Power of the Workforce. Boston, MA: Stanford Graduate School of Business, Harvard Business School Press.

Pfeffer, Jeffrey. 1998. The Human Equation: Building Profits by Putting People First. Boston, MA: Harvard Business School Press.

Porter, Lynam W., Steers, Richard M., Mowday, Richard T. and Boulian, Paul V. 1974. 'Organizational commitment, job satisfaction, and turnover among psychiatric technicians', Journal of Applied Psychology, Vol. 59, No. 5, pp. 603-610.

Katz, Ralph 1978. 'Job longevity as a situational factor in job satisfaction', Administrative Science Quarterly, Vol. 23, No. 2, pp. 204-222.

Kemp, Nigel J. and Cook, John D. 1983. 'Job longevity and growth need strength as joint moderators of the task design-job satisfaction relationship', Human Relations, Vol. 36, No. 10, pp. 883-898.

Roche, William 1999. 'In search of commitment-oriented human resource management practices and the conditions that sustain them', Journal of Management Studies, Vol. 36, No. 5, pp. 653-678.

Rusbult, Caryl E. and Farrell, Dan 1983. 'A longitudinal test of the investment model: the impact on job satisfaction, job commitment, and turnover of variations in rewards, costs, alternatives and investments', Journal of Applied Psychology, Vol. 68, No. 3, pp. 429-438.

Rothwell, Sheila 1995. 'Human resource planning', in Storey, John (Ed.) Human Resource Management: A Critical Text. London: Routledge.

THE LEARNING, INNOVATION AND KNOWLEDGE (LINK) RESEARCH CENTRE WORKING PAPER SERIES WP 01-03

http://www.link.dcu.ie/publications/workingpaperseries/

(c) 2003, LInK, Edel Conway

Contact: edel.conway@dcu.ie 
Schalk, René and Freese, Charissa 1997. 'New facets of commitment in response to organisational change: research trends and the Dutch experience', in Cooper, Cary L. and Rousseau, Denise M. (Eds.) Trends in Organisational Behaviour. New York: Wiley. pp. 107-123.

Shore, Lynn M. and Martin, H. J. 1989. 'Job satisfaction and organizational commitment in relation to work performance and turnover intentions', Human Relations, Vol. 42, pp. 625-638.

Shouksmith, George 1994. 'Variables related to organisational commitment in health professionals', Psychological Reports, Vol. 4, No. 3, pp. 707-711.

Somers, Mark John 1995. 'Organisational commitment, turnover, and absenteeism: an examination of direct and interaction effects', Journal of Organizational Behaviour, Vol.16, pp. 49-58.

Somers, Mark John and Birnbaum, Dee 1998. 'Work-related commitment and job performance: it's also the nature of performance that counts', Journal of Organizational Behavior, Vol. 19, No. 6, pp. 621-634.

Sturges, Jane, Guest, David and Mackenzie-Davey, Kate 2000. 'Who's in charge? Graduates' attitudes to and experiences of career management and their relationship with organisational commitment', European Journal of Work and Organisational Psychology, Vol. 9, No. 3, pp. 351-370.

Suliman, Abubakr and Iles, Paul 2000. 'Is continuance commitment beneficial to organisations? Commitment-performance relationship: a new look', Journal of Managerial Psychology, Vol. 15, No. 5, pp. 407-422.

Super, Donald E. 1957. The Psychology of Careers: An Introduction to Vocational Development. New York: Harper and Row.

Van Maanen, John. and Schein, Edgar H. 1979. Towards a theory of organisational socialization', in Staw, Barry M. (Ed.) Research in Organizational Behavior, Vol. 1, Greenwich, CT: JAI Press, pp. 209-264.

Walton, Richard E. 1985. 'Towards a strategy of eliciting employee commitment based on policies of mutuality', in Walton, Richard E. and Lawrence, Paul R. (Eds.) HRM: Trends and Challenges. Boston: Harvard Business School.

Whitfield, Keith and Poole, Michael 1997. 'Organising employment for high performance: theories, evidence and policy', Organisation studies, Vol. 18, No. 5, pp. 745-764.

Wiener, Yoash 1982. 'Commitment in organizations: a normative view', Academy of Management Review, Vol. 7, No. 3, pp. 418-428.

Wood, Stephen 1995. 'The four pillars of HRM: are they connected?', Human Resource Management Journal, Vol. 5, No. 5, pp. 48-58.

Wood, Stephen 1996. 'High commitment management and payment systems', Journal of Management Studies, Vol. 33, No. 1, pp. 53 - 76.

THE LEARNING, INNOVATION AND KNOWLEDGE (LINK) RESEARCH CENTRE WORKING PAPER SERIES WP 01-03

http://www.link.dcu.ie/publications/workingpaperseries/

(c) 2003, LInK, Edel Conway

Contact: edel.conway@dcu.ie 
Wood, Stephen 1999. 'Getting the measure of the transformed high-performance organisation', British Journal of Industrial Relations, Vol. 37, No. 3, pp. 391-417.

Wood, Stephen and de Menezes, Lilian 1998. 'High commitment management in the UK: evidence from the workplace industrial relations survey and employers' manpower and skills practices survey', Human Relations, Vol. 51, No. 4, pp. 485515.

Youndt, Mark, Snell, Scott, Dean, James and Lepak, David 1996. 'Human resource management, manufacturing strategy, and firm performance', Academy of Management Journal, Vol. 39, No. 4, pp. 836-866. 
TABLES AND FIGURES

Table 1: Summary of 'High Commitment', 'High Performance', 'Best' HR Practices

\begin{tabular}{|c|c|c|}
\hline HR Practice Areas & Key Characteristics & $\begin{array}{c}\text { Examples From the } \\
\text { Literature }\end{array}$ \\
\hline $\begin{array}{l}\text { Recruitment \& } \\
\text { Selection }\end{array}$ & $\begin{array}{l}\text { Selective recruiting/ recruitment } \\
\text { intensity; Focus on trainability and } \\
\text { commitment; Human relations } \\
\text { skills in selection }\end{array}$ & $\begin{array}{l}\text { Huselid, 1995; Ichniowski et } \\
\text { al, 1997; Wood, 1996, 1999a. }\end{array}$ \\
\hline Socialisation & Extensive socialisation & $\begin{array}{l}\text { Arthur, 1994; Patterson et al, } \\
1997 .\end{array}$ \\
\hline Job Design & $\begin{array}{l}\text { Broad job descriptions; Flexible } \\
\text { working; Job rotation; Teamwork }\end{array}$ & $\begin{array}{l}\text { Arthur, 1994; Ichniowski et } \\
\text { al, 1997; MacDuffie, 1995; } \\
\text { Patterson et al, 1997; Wood, } \\
1996 .\end{array}$ \\
\hline $\begin{array}{l}\text { Communication/ } \\
\text { Participation }\end{array}$ & $\begin{array}{l}\text { Information sharing; Attitude } \\
\text { surveys; Grievance/ conflict } \\
\text { resolution; Team briefing; } \\
\text { Suggestion schemes }\end{array}$ & $\begin{array}{l}\text { Arthur, 1994; Huselid, 1995; } \\
\text { Lawler et al, 1998; } \\
\text { MacDuffie, 1995; Wood, } \\
\text { 1996; Wood \& DeMenezes, } \\
\text { 1998. }\end{array}$ \\
\hline Training & $\begin{array}{l}\text { Induction training; Formal training; } \\
\text { Re-training; On-the-job training; } \\
\text { Cross-training }\end{array}$ & $\begin{array}{l}\text { Arthur, 1994; Huselid, 1995; } \\
\text { MacDuffie, 1995; Patterson } \\
\text { et al, 1997; Wood, 1996, } \\
\text { 1999a. }\end{array}$ \\
\hline $\begin{array}{l}\text { Performance } \\
\text { Management }\end{array}$ & $\begin{array}{lcc}\text { Formal Appraisals; } & \text { Results- } \\
\text { oriented; } & \text { Merit-based } & \end{array}$ & $\begin{array}{l}\text { Delery and Doty, 1996; } \\
\text { Huselid, 1995; Wood, 1996, } \\
\text { Youndt et al, 1996. }\end{array}$ \\
\hline $\begin{array}{l}\text { Career } \\
\text { Development }\end{array}$ & $\begin{array}{l}\text { Promotion from within; Career } \\
\text { ladders and progression, Internal } \\
\text { recruitment }\end{array}$ & $\begin{array}{l}\text { Huselid, 1995; Pfeffer, 1994, } \\
\text { 1998; Wood, 1996, 1999a. }\end{array}$ \\
\hline Employee Reward & $\begin{array}{l}\text { High rewards; Salaried workers; } \\
\text { Incentive pay; Team rewards; } \\
\text { Extensive benefits; Profit sharing; } \\
\text { Stock ownership }\end{array}$ & $\begin{array}{l}\text { Arthur, 1994; Delery and } \\
\text { Doty, 1996; Huselid, 1995; } \\
\text { Ichniowski et al, 1997; } \\
\text { MacDuffie, 1995. }\end{array}$ \\
\hline Job Security & High job security & $\begin{array}{l}\text { Delery and Doty, 1996; } \\
\text { Huselid, 1995; Wood } 1996 .\end{array}$ \\
\hline
\end{tabular}

THE LEARNING, INNOVATION AND KNOWLEDGE (LINK) RESEARCH CENTRE WORKING PAPER SERIES WP $01-03$ 
Table 2: Human Resource Management Practices: Sample Items

\begin{tabular}{|l|l|}
\hline HR PRACTICE AREAS & SAMPLE ITEMS \\
\hline Resourcing and Integration & $\begin{array}{l}\text { This company makes every effort to attract and hire the } \\
\text { most highly skilled people in the industry }\end{array}$ \\
\hline Communication & $\begin{array}{l}\text { All important information about the company is } \\
\text { communicated to employees }\end{array}$ \\
\hline Job Design & $\begin{array}{l}\text { My job is designed in a way which enables me to make full } \\
\text { use of my skills and abilities }\end{array}$ \\
\hline Socialisation & $\begin{array}{l}\text { The organisation takes sufficient steps to ensure that new } \\
\text { employees know 'how things are done around here' }\end{array}$ \\
\hline Training & $\begin{array}{l}\text { Overall, I feel that the training I receive enables me to do } \\
\text { my job efficiently }\end{array}$ \\
\hline Career Development & I feel I have all the opportunities I need to be promoted \\
\hline Performance Management & $\begin{array}{l}\text { I understand the basis upon which my performance is } \\
\text { assessed }\end{array}$ \\
\hline Job Security & I feel I have a high degree of job security here \\
\hline Employability & $\begin{array}{l}\text { The skills I have developed here would be useful in another } \\
\text { similar organisation }\end{array}$ \\
\hline Reward & $\begin{array}{l}\text { I feel that the pay I receive accurately reflects my } \\
\text { contribution }\end{array}$ \\
\hline Teamwork & There is not enough emphasis on teamwork here \\
\hline
\end{tabular}




\section{Table 3: Correlations and Reliabilities for Measures}

\begin{tabular}{|c|c|c|c|c|c|c|c|c|c|c|c|c|c|c|c|c|c|c|c|c|}
\hline MEASURES & $\mathbf{M}$ & SD & 1. & 2. & 3. & 4. & 5. & 6. & 7. & 8. & 9. & 10. & 11. & 12. & 13. & 14. & 15. & 16. & 17. & 18. \\
\hline 1. Affective & -.19 & .72 & $(.81)$ & & & & & & & & & & & & & & & & & \\
\hline 2. Continuance & -.40 & .69 & .28 & $(.76)$ & & & & & & & & & & & & & & & & \\
\hline 3. Normative & -.45 & .62 & .40 & .14 & $(.73)$ & & & & & & & & & & & & & & & \\
\hline 4. Involvement & -.11 & .87 & .41 & .08 & .15 & $(.84)$ & & & & & & & & & & & & & & \\
\hline 5. Resourcing & .02 & .72 & .33 & .08 & .18 & .40 & $(.74)$ & & & & & & & & & & & & & \\
\hline 6. Training & -.12 & .87 & .36 & .09 & .09 & .49 & .43 & $(.77)$ & & & & & & & & & & & & \\
\hline 7. Career Development & -.42 & .79 & .44 & .01 & .20 & .41 & .44 & .52 & $(.72)$ & & & & & & & & & & & \\
\hline 8. Performance Management & .23 & .80 & .38 & .13 & .17 & .43 & .28 & .40 & .45 & $(.80)$ & & & & & & & & & & \\
\hline 9. Job Security* & .25 & 1.15 & .17 & .11 & -.02 & .19 & .07 & .15 & .07 & .14 & & & & & & & & & & \\
\hline 10. Employability & 1.09 & .68 & .26 & -.12 & .01 & .28 & .28 & .33 & .34 & .36 & .14 & $(.72)$ & & & & & & & & \\
\hline 11. Reward & -.08 & .86 & .37 & .25 & .16 & .16 & .28 & .20 & .36 & .27 & .10 & .20 & $(.82)$ & & & & & & & \\
\hline 12. Job Design & .43 & .90 & 46 & -.06 & .16 & .28 & .23 & .36 & .57 & .40 & .05 & .35 & .27 & $(.76)$ & & & & & & \\
\hline 13.Teamwork & .12 & .96 & .30 & .18 & .11 & .50 & .25 & .39 & .27 & .48 & .17 & .23 & .08 & .11 & $(.59)$ & & & & & \\
\hline 14. Employee Age & 2.51 & .85 & .12 & .08 & .01 & -.22 & -.13 & -.06 & .04 & -.04 & -.23 & -.06 & .14 & .21 & -.15 & & & & & \\
\hline 15. Tenure (years) & 6.6 & 1.42 & .24 & .29 & .02 & -.16 & -.20 & -.02 & -.00 & .04 & -.06 & .02 & .24 & .11 & -.04 & .62 & & & & \\
\hline 16. Position & 2.30 & 1.45 & .16 & -.23 & -.12 & -.10 & .09 & .08 & .27 & .04 & -.20 & .18 & .10 & .38 & -.11 & .43 & .31 & & & \\
\hline 17. Education & 4.31 & 1.12 & -.04 & -.27 & -.26 & .05 & .07 & .12 & .19 & .05 & -.01 & .23 & -.00 & .19 & -.02 & -.01 & -.20 & .32 & & \\
\hline 18.Gender & 1.51 & .50 & -.06 & -.09 & .04 & .01 & .03 & -.03 & -.05 & -.05 & .17 & -.07 & -.03 & -.11 & .00 & -.19 & -.12 & -.28 & -.16 & \\
\hline
\end{tabular}

Note: All coefficients above .12 are significant at $p<0.05$, and above .16 are significant at $p<0.01$.

$*$ Single item measures above .09 are significant at $\mathrm{p}<0.05$, and above .12 are significant at $\mathrm{p}<0.01$.

Scale reliabilities for relevant measures are reported in parentheses in the upper diagonal for each variable. 
Table 4: Partial Correlations: Commitment and Career Stage Variables

\begin{tabular}{|l|c|c|c|c|}
\hline & Employee Age & $\begin{array}{c}\text { Employee Age } \\
\text { (Tenure) }\end{array}$ & $\begin{array}{c}\text { Organisational } \\
\text { Tenure }\end{array}$ & $\begin{array}{c}\text { Organisational } \\
\text { Tenure } \\
\text { (Age) }\end{array}$ \\
\hline $\begin{array}{l}\text { Affective } \\
\text { Commitment }\end{array}$ & $.12^{*}$ & -.03 & $.24^{* *}$ & $.21^{* *}$ \\
\hline $\begin{array}{l}\text { Continuance } \\
\text { Commitment }\end{array}$ & .08 & $-.13^{*}$ & $.29^{* *}$ & $.31^{* *}$ \\
\hline $\begin{array}{l}\text { Normative } \\
\text { Commitment }\end{array}$ & .01 & .00 & .02 & .01 \\
\hline
\end{tabular}

Note: Variable in parentheses has been partialled out. * $p<0.05, * * p<0.01$

Table 5: Partial Correlations: HR Practice Areas and Career Stage

\begin{tabular}{|l|c|c|c|c|}
\hline HR Practice Area & Age & $\begin{array}{c}\text { Age } \\
\text { (Tenure) }\end{array}$ & Tenure & $\begin{array}{c}\text { Tenure } \\
\text { (Age) }\end{array}$ \\
\hline Employee Involvement & $-.22^{* *}$ & $-.15^{*}$ & $-.16^{*}$ & -.05 \\
\hline Resourcing \& Integration & $-.13^{*}$ & -.01 & $-.20^{* *}$ & $-.16^{* *}$ \\
\hline Training & -.06 & -.05 & -.02 & .02 \\
\hline Career development & .04 & .05 & -.00 & -.03 \\
\hline $\begin{array}{l}\text { Performance } \\
\text { Management }\end{array}$ & -.04 & -.08 & .04 & .08 \\
\hline Job Security & $-.23^{* *}$ & $-.19^{* *}$ & $-.06^{*}$ & .01 \\
\hline Employability & -.06 & -.08 & .02 & .07 \\
\hline Reward & $.14^{*}$ & -.01 & $.24^{* *}$ & $.20^{* *}$ \\
\hline Job Design & $.21^{*}$ & .12 & .11 & -.00 \\
\hline Teamwork & $-.15^{*}$ & $-.16^{*}$ & -.04 & .07 \\
\hline
\end{tabular}

Note: Variables in parentheses have been partialled out. * p $<0.05, * * p<0.01$

Table 6: Partial Correlations: Career Stage, HRM Practice Areas and Affective Commitment

\begin{tabular}{|l|c|c|c|c|c|c|}
\hline & $\begin{array}{c}<\mathbf{3 0} \\
\text { yrs. }\end{array}$ & $\mathbf{3 1 - 4 0}$ yrs. & $\mathbf{4 1 +}$ yrs. & $<\mathbf{2}$ yrs. & $\mathbf{2 - 1 0}$ yrs. & $\mathbf{1 0}$ yrs. + \\
\hline Involvement & $.47^{* * *}$ & $.38^{* *}$ & $.46^{*}$ & $.42^{* * *}$ & $.44^{* * *}$ & $.47^{* * *}$ \\
\hline $\begin{array}{l}\text { Resourcing \& } \\
\text { Integration }\end{array}$ & $.40^{* * *}$ & .17 & $.44^{*}$ & $.35^{* *}$ & $.34^{* *}$ & $.31^{*}$ \\
\hline Training & $.46^{* * *}$ & .22 & .30 & $.38^{* *}$ & $.36^{* *}$ & $.46^{* * *}$ \\
\hline Career Devel. & $.44^{* * *}$ & $.44^{* * *}$ & .32 & $.47^{* * *}$ & $.37^{* *}$ & $.44^{* *}$ \\
\hline $\begin{array}{l}\text { Performance } \\
\text { Mgt. }\end{array}$ & $.36^{* * *}$ & $.28^{*}$ & $.53^{* *}$ & $.38^{* *}$ & $.24 *$ & $.45^{* *}$ \\
\hline Job Security & $.25^{* *}$ & $.38^{* *}$ & .24 & .17 & $.28^{* *}$ & $.33^{*}$ \\
\hline Employability & $.23^{* *}$ & .17 & $.53^{* *}$ & .21 & $.21^{* *}$ & $.32^{*}$ \\
\hline Reward & $.34^{* * *}$ & .11 & $.42^{*}$ & .20 & $.32^{* *}$ & $.36^{* *}$ \\
\hline Job Design & $.47^{* * *}$ & $.43^{* *}$ & .29 & $.49^{* * *}$ & $.39^{* * *}$ & $.44^{* *}$ \\
\hline Teamwork & $.32^{* * *}$ & $.32^{*}$ & .21 & $.39^{* *}$ & .21 & $.34^{*}$ \\
\hline n. & 130 & 58 & 22 & 72 & 85 & 53 \\
\hline
\end{tabular}

THE LEARNING, INNOVATION AND KNOWLEDGE (LINK) RESEARCH CENTRE WORKING PAPER SERIES WP $01-03$ 
Table 7: Multiple Correlations: Affective Commitment Regressed on Career Stage Variables, HRM Practice Areas and their Interactions

\begin{tabular}{|l|c|c|c|c|}
\hline & Career Stage & $\begin{array}{c}\text { HR Practice } \\
\text { Area }\end{array}$ & $\begin{array}{c}\text { Age X HR } \\
\text { Practice Area }\end{array}$ & $\begin{array}{c}\text { Tenure X HR } \\
\text { Practice Area }\end{array}$ \\
\hline $\begin{array}{l}\text { Employee } \\
\text { Involvement }\end{array}$ & $.21^{*}$ & $.49^{* * *}$ & .49 & .49 \\
\hline $\begin{array}{l}\text { Resourcing \& } \\
\text { Integration }\end{array}$ & $21^{*}$ & $.41^{* * *}$ & .41 & .42 \\
\hline Training & $.22^{*}$ & $.44^{* * *}$ & .44 & .44 \\
\hline Career development & $.21^{*}$ & $.49 * * *$ & .49 & .49 \\
\hline $\begin{array}{l}\text { Performance } \\
\text { Management }\end{array}$ & $.21^{*}$ & $.42^{* * *}$ & .42 & .42 \\
\hline Job Security & $.22^{*}$ & $.31^{* * *}$ & .31 & .31 \\
\hline Employability & $.21^{*}$ & $.34 * * *$ & .34 & .35 \\
\hline Employee Reward & $.21^{*}$ & $.41^{* * *}$ & .41 & .41 \\
\hline Job Design & $.21^{*}$ & $.50^{* * *}$ & .50 & .50 \\
\hline
\end{tabular}

Table 8: Partial Correlations: Career Stage, HRM Practice Areas and Continuance Commitment

\begin{tabular}{|l|c|c|c|c|c|c|}
\hline & <30 yrs. & $\mathbf{3 1 - 4 0}$ yrs. & $\mathbf{4 1 +}$ yrs. & < 2 yrs. & $\mathbf{2 - 1 0}$ yrs. & $\mathbf{1 0}$ yrs. + \\
\hline Involvement & .19 & .04 & -.17 & .08 & .11 & .07 \\
\hline $\begin{array}{l}\text { Resourcing \& } \\
\text { Integration }\end{array}$ & .10 & .20 & .11 & .08 & .08 & .13 \\
\hline Training & .17 & .21 & -.24 & .23 & .12 & .06 \\
\hline Career Devel. & .06 & .01 & -.21 & .18 & -.12 & -.05 \\
\hline $\begin{array}{l}\text { Performance } \\
\text { Mgt. }\end{array}$ & $.18^{*}$ & -.02 & -.06 & .15 & .00 & .09 \\
\hline Job Security & $.19 *$ & .22 & -.18 & .07 & $.29 * *$ & .15 \\
\hline Employability & -05 & $-.29 *$ & -.28 & -.19 & -.17 & -.11 \\
\hline Reward & $.22 *$ & .18 & $.42^{*}$ & .03 & .19 & $.33^{*}$ \\
\hline Job Design & -.06 & -.05 & -.23 & -.03 & -.18 & -.01 \\
\hline Teamwork & $.22 *$ & .03 & -.08 & .22 & .10 & .08 \\
\hline n. (Range) & 130 & 58 & 22 & 72 & 85 & 53 \\
\hline
\end{tabular}


Table 9: Multiple Correlations: Continuance Commitment Regressed on Career Stage Variables, HRM Practice Areas and their Interactions

\begin{tabular}{|c|c|c|c|c|}
\hline & Career Stage & $\begin{array}{c}\text { HR Practice } \\
\text { Area }\end{array}$ & $\begin{array}{c}\text { Age X HR } \\
\text { Practice Area }\end{array}$ & $\begin{array}{l}\text { Tenure X HR } \\
\text { Practice Area }\end{array}$ \\
\hline $\begin{array}{l}\text { Employee } \\
\text { Involvement }\end{array}$ & $.35 * * *$ & .36 & .38 & .42 \\
\hline $\begin{array}{l}\text { Resourcing \& } \\
\text { Integration }\end{array}$ & $.36 * * *$ & .38 & .38 & .38 \\
\hline Training & $.35 * * *$ & .37 & .37 & .37 \\
\hline $\begin{array}{l}\text { Career } \\
\text { development }\end{array}$ & $.36 * * *$ & .36 & .36 & .37 \\
\hline $\begin{array}{l}\text { Performance } \\
\text { Management }\end{array}$ & $.35 * * *$ & .37 & $.39 *$ & .39 \\
\hline Job Security & $.35 * * *$ & $.38^{* *}$ & .38 & .40 \\
\hline Employability & $.35 * * *$ & $.37 *$ & .39 & .39 \\
\hline $\begin{array}{l}\text { Employee } \\
\text { Reward }\end{array}$ & $.36 * * *$ & $.40 * *$ & .40 & .41 \\
\hline Job Design & $.35 * * *$ & .36 & .37 & .37 \\
\hline
\end{tabular}

Table 10: Partial Correlations: HRM Practice Areas and Normative Commitment

\begin{tabular}{|l|c|c|c|c|c|c|}
\hline & $<\mathbf{3 0}$ yrs. & $\mathbf{3 1 - 4 0}$ yrs. & $\mathbf{4 1 +}$ yrs. & $<\mathbf{2}$ yrs. & $\mathbf{2 - 1 0}$ yrs. & 10 yrs. + \\
\hline Involvement & $.17^{*}$ & -.08 & .27 & $.33^{* *}$ & -.05 & .10 \\
\hline $\begin{array}{l}\text { Resourcing \& } \\
\text { Integration }\end{array}$ & $.25^{* *}$ & -.14 & .40 & .16 & $.24^{*}$ & -.07 \\
\hline Training & .16 & -.16 & .13 & .12 & .13 & -.10 \\
\hline Career Devel. & $.37^{* * *}$ & -.13 & -.04 & $.45^{* * *}$ & .08 & -.13 \\
\hline $\begin{array}{l}\text { Performance } \\
\text { Mgt. }\end{array}$ & $.20^{*}$ & -.08 & .27 & $.29^{*}$ & .05 & -.02 \\
\hline Job Security & .03 & .03 & .12 & .00 & $.21^{*}$ & -.19 \\
\hline Employability & .15 & $-.34 * *$ & .25 & .13 & -.05 & -.11 \\
\hline Reward & $.20^{*}$ & -.05 & .36 & .03 & $.22^{*}$ & .21 \\
\hline Job Design & $.33^{* * *}$ & -.18 & .01 & $.44^{* * *}$ & .04 & -.12 \\
\hline Teamwork & .13 & -.05 & .06 & .20 & -.01 & .02 \\
\hline n. (Range) & 130 & 58 & 22 & 72 & 85 & 53 \\
\hline
\end{tabular}


Table 11: Multiple Correlations: Normative Commitment Regressed on Career Stage Variables, HRM Practice Areas and their Interactions

\begin{tabular}{|l|c|c|c|c|}
\hline & $\begin{array}{c}\text { Career } \\
\text { Stage }\end{array}$ & $\begin{array}{c}\text { HR Practice } \\
\text { Area }\end{array}$ & $\begin{array}{c}\text { Age X HR } \\
\text { Practice Area }\end{array}$ & $\begin{array}{c}\text { Tenure X HR } \\
\text { Practice Area }\end{array}$ \\
\hline $\begin{array}{l}\text { Employee } \\
\text { Involvement }\end{array}$ & .08 & $.15^{*}$ & .15 & $.22^{*}$ \\
\hline $\begin{array}{l}\text { Resourcing \& } \\
\text { Integration }\end{array}$ & .07 & $.17^{*}$ & .19 & .20 \\
\hline Training & .08 & .11 & .12 & .12 \\
\hline $\begin{array}{l}\text { Career } \\
\text { development }\end{array}$ & .09 & $.19^{* *}$ & $.27^{* *}$ & $.30^{*}$ \\
\hline $\begin{array}{l}\text { Performance } \\
\text { Management }\end{array}$ & .07 & $.15^{*}$ & .17 & .19 \\
\hline Job Security & .08 & .08 & .09 & .12 \\
\hline Employability & .08 & .08 & $.15^{*}$ & .15 \\
\hline Employee Reward & .06 & $.18^{* *}$ & .18 & .21 \\
\hline Job Design & .08 & $.16^{*}$ & $.24^{* *}$ & .27 \\
\hline
\end{tabular}

